\title{
Radiographic Quality of Root Canal Fillings Performed in a Postgraduate Program in Endodontics
}

\author{
Suelleng Maria Cunha SANTOS ${ }^{1}$ \\ Janir Alves SOARES ${ }^{1}$ \\ Carlos Augusto Santos CÉSAR ${ }^{1}$ \\ Manoel BRITO-JÚNIOR ${ }^{2}$ \\ Allyson Nogueira MOREIRA ${ }^{3}$ \\ Cláudia Silami de MAGALHÃES ${ }^{3}$
}

${ }^{1}$ Dental School, Federal University of Vales do Jequitinhonha e Mucuri, Diamantina, MG, Brazil
2Dental School, State University of Montes Claros, Montes Claros, MG, Brazil
${ }^{3}$ Dental School, Federal University of Minas Gerais, Belo Horizonte, MG, Brazil

The aim of this study was to evaluate the standard quality of 1,347 root fillings performed by postgraduate students in Endodontics according to 3 radiographic quality parameters. The analyzed quality parameters included apical extension (AE), taper (TA) and homogeneity (HO), which received scores S2 (ideal standard), S1 (slight deviation) or S0 (accentuated deviation). A perfect filling $(\mathrm{PF})$ received S2 for all parameters. In the absence of one or two S2 score, the fillings were deemed as satisfactory (SF) or deficient (DF), respectively. The results showed $51.7 \%, 41.5 \%$ and $6.8 \%$ of PF, SF, and DF, respectively. AE, TA, and HO presented equivalent quality parameters in root-filled canals of mandibular incisors and mandibular premolars ( $p>0.05)$. Conversely, in maxillary incisors, canines and distal root of mandibular molars, significant differences $(p<0.05)$ were found between 2 parameters. Besides, there were significant differences $(\mathrm{p}<0.05)$ among the measured parameters in root-filled canals of maxillary premolars, all root canals of the maxillary molars and mesial root of the mandibular molars. AE showed the lowest frequency of S2 score for all groups. In conclusion the prevalence of perfect, satisfactory and deficient fillings varied significantly according to the root canal group. The quality parameters categorized fillings in 3 complexity degrees. AE was the most critical parameter of quality in root canal fillings.

Key Words: Endodontic treatment quality, radiographic evaluation, root canal treatment, root canal filling.

\section{INTRODUCTION}

Root canal filling represents an essential step in endodontic treatment (1). There is substantial evidence that the technical quality of root canal treatment has a significant influence on endodontic therapy outcomes $(1,2)$. Epidemiologic studies conducted in many countries have shown high prevalence of poor technical quality filling associated with periapical radiolucency (1-6), which raises an important public health problem with medical, economical, and ethical repercussions. Among the risk factors involving in the development of periapical radiolucency, the quality of root canal filling was found to have the most critical impact $(1,4)$. Thus, efforts should be made to improve the quality of the obturation seen in radiographs.
Improvements in clinical performance require the interaction of many factors involving knowledge, training, ability and the use of technology (7-11). Postgraduate courses represent major contributors to this improvement process $(2,6,7)$.

This study evaluated the quality of fillings performed by postgraduate students in Endodontics in different root groups as a function of three radiographic parameters. It was hypothesized that there is no difference in the radiographic quality of canal filling in different root groups when treated by graduate students.

\section{MATERIAL AND METHODS}

In this cross-sectional study, clinical and radiographic records were obtained from dental charts 
of patients attending the Postgraduate Program in Endodontics of the Federal University of Vales do Jequitinhonha e Mucuri, MG, Brazil, between 2002 and 2005. For calibration of the operative procedures, all postgraduate students underwent extensive laboratory training of the instrumentation and filling techniques in all groups of teeth.

The endodontic treatment followed a predefined protocol. The root canals were explored after coronal access with \#10 K-files (Dentsply/Maillefer Instruments, Ballaigues, Switzerland). Chemomechanical preparation was done with hand instruments according to a crowndown technique. Gates-Glidden drills (Dentsply/ Maillefer) and stainless steel (FlexoFile and Hedströen) and Ni-Ti (Nitiflex; Dentsply/Maillefer) instruments were used. The canals were irrigated with $1,2.5$ or 4-6\% sodium hypochlorite (Biodinâmica Laboratórios, São Paulo, SP, Brazil) for cases of vital pulp, necrotic pulp or pulp necrosis associated with periapical lesion, respectively. Irrigation was performed using a Luer Lock syringe with $27 \mathrm{G}$ needle.

The coronal and middle thirds of the canals were prepared sequentially with sizes 15-35 K-FlexoFile followed by Gates Glidden drills. Thus, the working length (WL) was determined using an electronic apex locator (Apex Finder; Analytic Technology, Redmond, WA, USA), followed by periapical radiography. The WL was set to $1.5 \mathrm{~mm}$ short of the radiographic apex. Apical patency was achieved in all root canals with necrotic pulp. The apical third was instrumented to the master apical file.

Root canals were further instrumented with stepback enlargement in $1 \mathrm{~mm}$ increments to 3 or 4 sizes larger than the master apical file. After smear layer removal using $17 \%$ EDTA followed by a final rinse with sodium hypochlorite, the root canals were dried. Then, the main gutta-percha cone (Odous, Belo Horizonte, $\mathrm{MG}$, Brazil) was set to the WL and the canal was obturated by thermomechanical technique with gutta-percha cones and an epoxy resin-based endodontic sealer (Sealer 26; Dentsply, Petrópolis, RJ, Brazil). In order to verify the obturation quality, periapical radiographs were taken by the bisecting-angle technique and processed by the time-temperature method.

The root canals were topographically classified into 12 groups: maxillary incisor; mandibular incisor; maxillary canines; mandibular canines; buccal root of maxillary premolars; palatal root of maxillary premolars; mandibular premolars; mesiobuccal root of maxillary molars; distobuccal root of maxillary molars; palatal root of maxillary molars; mesial root of mandibular molars and distal root of mandibular molars. Only canals that were completely visible in the radiograph were evaluated. Incompletely formed roots, with internal resorptions or that were morphologically altered by previous procedural errors of coronal access or intracanal post preparations were excluded the from evaluation.

The radiographs were projected in a dark room and magnified 6 times onto a grid screen. They were independently evaluated by 3 examiners, including 2 professors and 1 endodontic resident, and none of the examiners were involved in providing care to the patients who were included in this study. Before the study, 40 periapical radiographs that were not included in the study were used to calibrate the examiners to detect a filling quality and evident complicating filling factors. In case of disagreement, the 3 examiners came to a consensus. The intraexaminer (Kappa $=0.82$ to 0.92 ) and interexaminer (Kappa $=0.76$ to 0.80 ) agreement was almost perfect.

The root canal was considered as a sampling unit and the filling quality was sensibly evaluated according the following parameters: i) apical extension (AE), ii) homogeneity (HO) and iii) taper (TA), and they were scored (S) from S0, S1, and S2. S2 corresponded to the ideal standard, while S1 and S0 referred to a slight and accentuated deviation from the ideal standard, respectively. The $\mathrm{S} 2$ frequency determined three quality standards for the fillings: perfect, satisfactory and deficient, as follows drawing in Figure 1.

The comparison of the proportions of scores between the parameters determined three degree complexities of the root-filled canals: i) low complexity - there was one combination among the 3 parameters, (i.e. $\mathrm{AE}=\mathrm{HO}, \mathrm{AE}=\mathrm{TA}$ and $\mathrm{HO}=\mathrm{TA}$ ); ii) medium complexity - there were two combinations among the parameters (i.e. $\mathrm{AE}=\mathrm{HO}, \mathrm{AE}=\mathrm{TA}$ and $\mathrm{HO} \neq \mathrm{TA}$ ); and iii) high complexity - there was one or neither combination among the parameters (i.e. $\mathrm{AE}=\mathrm{HO}, \mathrm{AE} \neq \mathrm{TA}$ and $\mathrm{HO} \neq \mathrm{TA}$, or $\mathrm{AE} \neq \mathrm{HO}, \mathrm{AE} \neq \mathrm{TA}$ and $\mathrm{HO} \neq \mathrm{TA}$ ).

Relevant clinical-radiographic aspects involving fractured instruments, calcified root canals, ledges, root perforations, and gutta-percha cone overextensions were evaluated as complicating filling factors.

Pearson's chi-square test was used to compare the results among root canal groups. The frequency score of quality parameters of the root canal groups was analyzed by Mann-Whitney and Fisher's Exact 
tests. Odds ratio (OR) and 95\% confidence interval (CI) were also calculated for association among complicating factors and standard filling quality.

\section{RESULTS}

During a time span of 4 years, 1,347 canals of maxillary $(\mathrm{n}=735,54.5 \%)$ and mandibular teeth $(\mathrm{n}=612,45.5 \%)$ were treated endodontically by students attending a Postgraduate Program in Endodontics. Overall, $91.5 \%$ were primary treatments $(\mathrm{n}=1.233)$ and $8.5 \%(\mathrm{n}=114)$ were endodontic retreatments. The second mesiobuccal root canal (MB2) was prepared and filled in $44(3.2 \%)$ maxillary molars. Radiographically, the main mesiobuccal canal (MB1) and MB2 merged in the middle-coronal segments in all roots. Because the small sample size and similar quality standard of fillings the maxillary and mandibular canines, as well as, the buccal and palatal root canals of maxillary premolars, were clustered into 2 groups.

Figure 2 shows the different standard quality among root-filled canal groups. The quality standard of root canal filling varied significantly among the groups; therefore, the null hypothesis was rejected. A similar prevalence of perfect $(51.7 \%)$ and satisfactory $(41.5 \%)$ fillings was observed, with only $6.8 \%$ of deficient fillings (Table 1). The mesiobuccal canals of maxillary molars presented fewer perfect fillings (35.9\%), but high rate of the satisfactory $(50.0 \%)$ and deficient (14.08\%) fillings $(p<0.05)$. The mandibular and maxillary incisors, canines and distal roots of mandibular molars presented a similar prevalence of perfect and satisfactory fillings ( $p>0.05$ ). The same occurred among mandibular premolars, mesiobuccal and distobuccal roots of maxillary molars, as well as mesial canals of mandibular molars ( $p>0.05$ ). On the other hand, all canals of anterior teeth and premolars presented similar prevalence among satisfactory and deficient fillings as well as perfect and deficient fillings ( $>00.05$ ).

A higher prevalence of filled canals in the posterior region $(\mathrm{p}<0.05)$ was observed $(\mathrm{n}=1,186$, $88.05 \%$ ). In comparison to satisfactory fillings, perfect fillings were more frequently observed in the anterior region (65.2\% versus $49.9 \%)$. In the posterior region, satisfactory fillings were more prevalent $(42.9 \%$ versus $31.1 \%$ ). The quality of fillings did not vary significantly as a function of the dental arch (maxillary or mandibular) or endodontic treatment type ( $\mathrm{p}>0.05)$.

Figure 3 shows the frequency of quality parameters according to the root canals groups. Homogeneity presented the highest prevalence of ideal standard scores, varying from 90.94 to $100.0 \%$, followed by taper ( 70.42 to $87.50 \%$ ). Apical extension presented the highest prevalence of S0 scores (poor quality), achieving $32.39 \%$ for the mesiobuccal canals of the maxillary molars $(\mathrm{p}<0.05)$. Mandibular incisors and mandibular premolars presented similar combination among the 3 parameters score being classified as of low complexity. The fillings that presented significant differences between two (maxillary incisor, canines, distal root of mandibular molar) or three (maxillary premolar, mesiobuccal, distobuccal and palatal roots of maxillary molar and, mesial root of mandibular molar) parameters were categorized as of medium or high complexity, respectively. The frequencies of scores S2 for apical extension were significantly lower than homogeneity and taper, except for the mandibular premolars and distobuccal canals of maxillary molar,

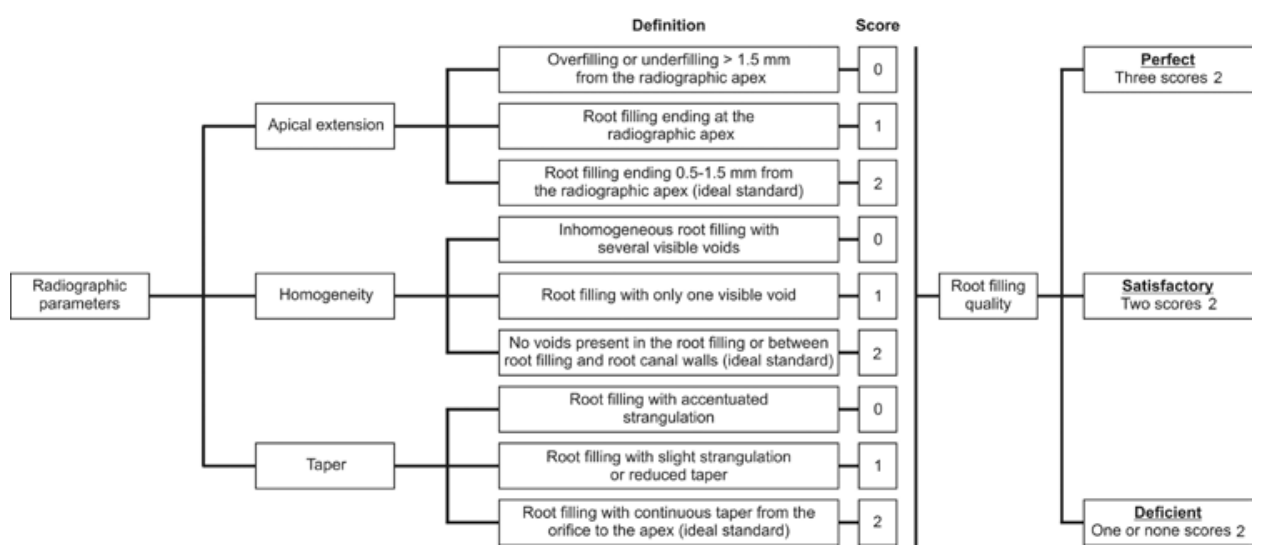

Figure 1. Schematic presentation of the root filling quality standard according to the radiographic parameters. 

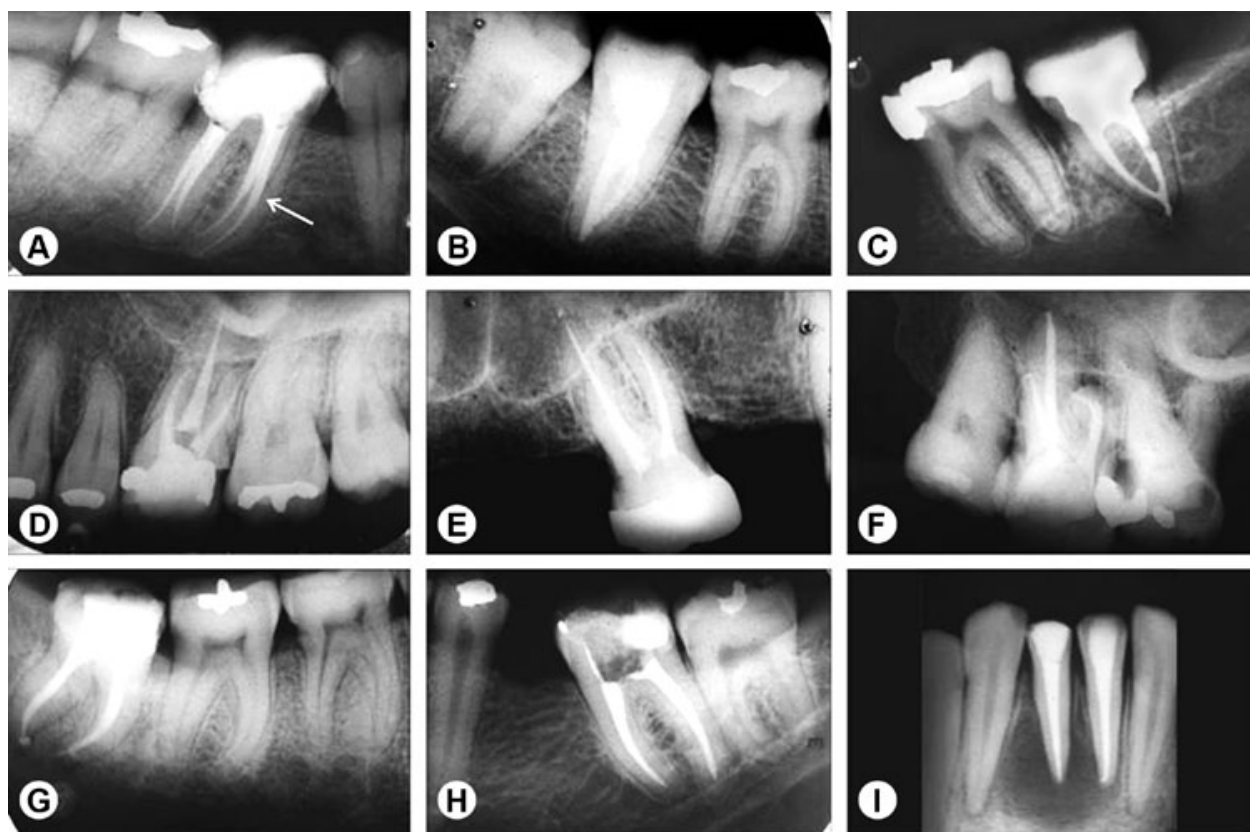

Figure 2. Panel of periapical radiographs of the root canal fillings and respective quality parameters. A) Tooth 46 - distal and mesiobuccal canals with perfect fillings $(\mathrm{AE}, \mathrm{HO}, \mathrm{TA}=\mathrm{S} 2)$ and mesiolingual canal with deficient filling (arrow) $(\mathrm{AE}=\mathrm{S} 0, \mathrm{TA}=\mathrm{S} 1)$. B) Tooth 47 - perfect filling in the distal canal $(\mathrm{AE}, \mathrm{HO}, \mathrm{TA}=\mathrm{S} 2)$ and satisfactory in the mesial canal $(\mathrm{TA}=\mathrm{S} 0)$. C) Tooth 37 - mesial canal with satisfactory filling $(\mathrm{AE}=\mathrm{S} 1)$ and distal canal with deficient filling $(\mathrm{AE}=\mathrm{S} 1, \mathrm{HO}=\mathrm{S} 1)$. D) Tooth 26 - all perfectly filled root canals $(\mathrm{AE}, \mathrm{HO}, \mathrm{TA}=\mathrm{S} 2)$. E) Tooth 16 - perfect palatal canal filling and satisfactory filling of mesiobuccal canals $(\mathrm{AE}=\mathrm{S} 0)$. F) Tooth 27 - mesiobuccal canal with deficient filling $(\mathrm{AE}=\mathrm{S} 1, \mathrm{TA}=\mathrm{S} 0)$, satisfactory filling of the palatal canal $(\mathrm{TA}=\mathrm{S} 1)$ and perfect filling of the distal canal $(\mathrm{AE}, \mathrm{HO}, \mathrm{TA}=\mathrm{S} 2)$. G) tooth 48 - mesial and distal canals with satisfactory fillings $(\mathrm{AE}=\mathrm{S} 1)$. H) Tooth 37 - mesial and distal canals with satisfactory fillings $(\mathrm{AE}=\mathrm{S} 0)$. I) teeth 31 and 41 with perfect filling $(\mathrm{AE}, \mathrm{HO}, \mathrm{TA}=\mathrm{S} 2)$.

Table 1. Quality of fillings as a function of root canals groups.

\begin{tabular}{|c|c|c|c|c|c|c|c|c|c|c|}
\hline \multirow{2}{*}{ Root canals groups } & \multirow{2}{*}{$\mathrm{N}$} & \multicolumn{3}{|c|}{ Perfect } & \multicolumn{3}{|c|}{ Satisfactory } & \multicolumn{3}{|c|}{ Deficient } \\
\hline & & $\mathrm{n}$ & $\%$ & $*$ & $\mathrm{n}$ & $\%$ & $* *$ & $\mathrm{n}$ & $\%$ & $* * *$ \\
\hline Maxillary incisors & 102 & 69 & 67.65 & $\mathrm{a}$ & 29 & 28.43 & $a, b, c, d$ & 4 & 3.92 & $\mathrm{a}$ \\
\hline Mandibular incisors & 16 & 12 & 75.00 & $a, b$ & 4 & 25.00 & $\mathrm{a}, \mathrm{b}, \mathrm{c}, \mathrm{d}$ & 0 & 0.00 & $\mathrm{a}, \mathrm{c}$ \\
\hline Canines & 43 & 24 & 55.81 & $\mathrm{a}, \mathrm{b}, \mathrm{c}$ & 17 & 39.53 & $\mathrm{a}, \mathrm{b}, \mathrm{c}, \mathrm{d}$ & 2 & 4.60 & $\mathrm{a}, \mathrm{c}$ \\
\hline Maxillary premolars & 177 & 93 & 52.54 & $\mathrm{~b}, \mathrm{c}$ & 74 & 41.81 & $\mathrm{a}, \mathrm{b}, \mathrm{c}, \mathrm{d}$ & 10 & 5.65 & $\mathrm{a}, \mathrm{c}$ \\
\hline Mandibular premolars & 70 & 33 & 47.14 & $\mathrm{~b}, \mathrm{~d}$ & 33 & 47.14 & $\mathrm{a}, \mathrm{b}, \mathrm{c}, \mathrm{d}$ & 4 & 5.71 & $\mathrm{a}, \mathrm{c}$ \\
\hline Mesiobuccal root of maxillary molars & 142 & 51 & 35.92 & $\mathrm{~d}$ & 71 & 50.00 & $\mathrm{~b}$ & 20 & 14.00 & $\mathrm{~b}$ \\
\hline Distobuccal root of maxillary molars & 133 & 76 & 57.14 & $b, d$ & 54 & 40.60 & $\mathrm{c}$ & 3 & 2.26 & $\mathrm{a}$ \\
\hline Palatal root of maxillary molars & 150 & 80 & 53.33 & $\mathrm{~b}, \mathrm{c}$ & 64 & 42.67 & $\mathrm{c}, \mathrm{d}$ & 6 & 4.00 & $\mathrm{a}$ \\
\hline Mesial root of mandibular molars & 298 & 137 & 45.97 & $\mathrm{c}, \mathrm{d}$ & 134 & 44.97 & $b, d$ & 27 & 9.06 & $\mathrm{~b}, \mathrm{c}$ \\
\hline Distal root of mandibular molars & 216 & 122 & 56.48 & $\mathrm{a}, \mathrm{b}$ & 79 & 36.57 & $b, d$ & 15 & 6.94 & $\mathrm{a}, \mathrm{c}$ \\
\hline Total & 1,347 & 697 & 51.70 & & 559 & 41.50 & & 91 & 6.80 & \\
\hline
\end{tabular}

Different letters in the same column indicate statistically significant differences among: *frequency of perfect and satisfactory fillings; **frequency of satisfactory and deficient fillings; ***frequency of perfect and deficient fillings (Pearson's chi-square test, $\mathrm{p}<0.05$ ). 
where the frequency score was similar to taper $(\mathrm{p}>0.05)$.

Among the complicating factors, it was observed greatest prevalence of overfilling $(2.67 \%)$, followed by ledge (1.26\%). Incorrect apical extension due to obstruction by calcification represented only $0.74 \%$ of the sample (Table 2). Root canal fillings affected by complicating factors were 3.2 times more likely to receive a lower quality score than fillings without complication $(\mathrm{OR}=3.210 ; 95 \% \mathrm{CI}=1.733-5.949)$.
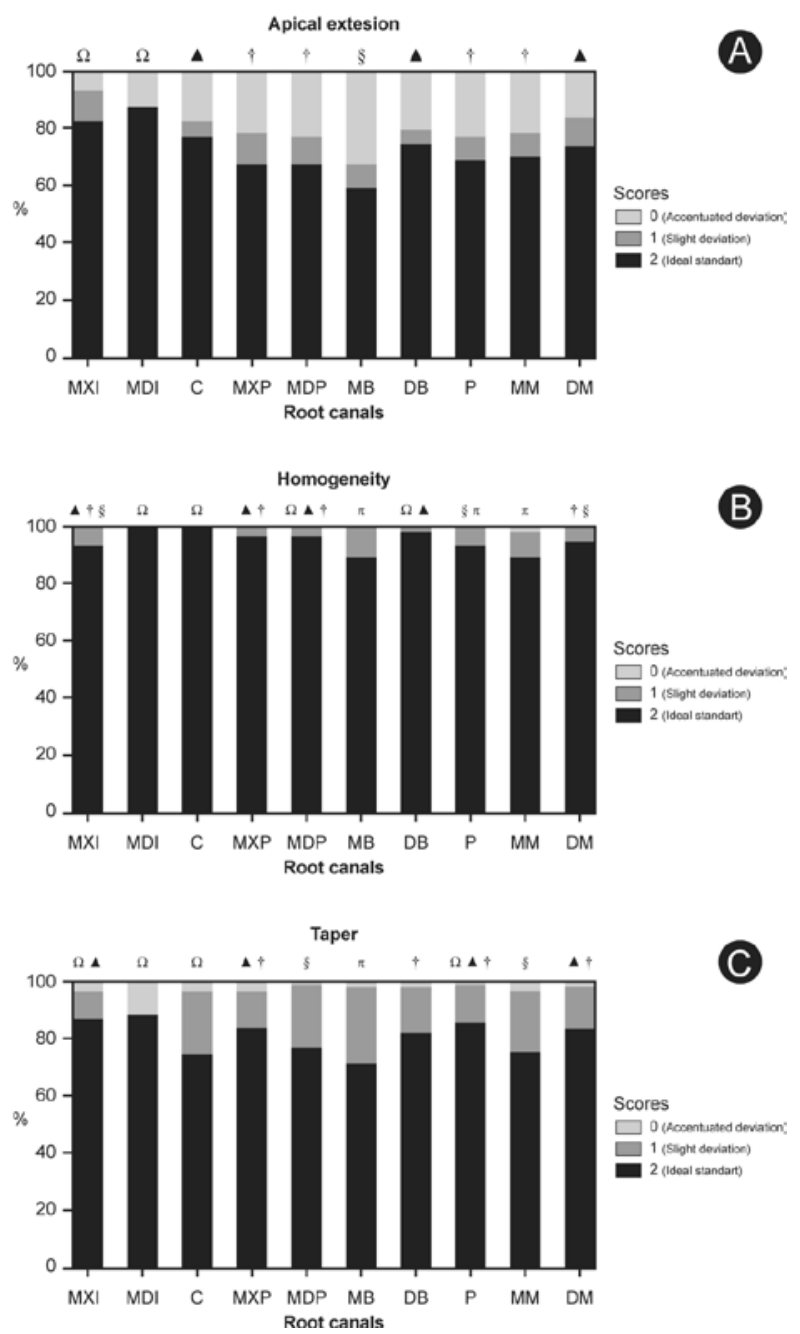

Figure 3. Frequency scores of quality parameters as a function of the root canals groups. (A) Apical extension, (B) Homogeneity and $(\mathrm{C})$ Taper. $\mathrm{MXI}=$ Maxillary incisors; $\mathrm{MDI}=$ Mandibular incisors; C- Canines; MXP $=$ Maxillary premolars; MDP = Mandibular premolars; $\mathrm{MB}=$ Mesiobuccal root of maxillary molars; $\mathrm{DB}=$ Distobuccal root of maxillary molars; $\mathrm{P}=$ Palatal root of maxillary molars; $\mathrm{MM}=$ Mesial root of mandibular molars; DM = Distal root of mandibular molars.

\section{DISCUSSION}

Several factors can influence the quality of root canal fillings. Regarding the site of treatment $(1,2,6)$, teeth have been most often adequately filled at the dental schools and hospitals, rather than at private clinics. From the operator point of view, it is generally assumed that treatment provided by well-trained endodontic specialists $(1,2)$ is characterized by better quality than those provided by general practitioners

Table 2. Complicating factors of root canal fillings and the related quality standard.

\begin{tabular}{|c|c|c|c|c|c|}
\hline \multirow{2}{*}{$\begin{array}{l}\text { Complicating } \\
\text { factors }\end{array}$} & \multirow{2}{*}{$\mathrm{n}$} & \multirow{2}{*}{$\%$} & \multicolumn{3}{|c|}{ Quality of fillings } \\
\hline & & & $\mathrm{PF}$ & $\mathrm{SF}$ & $\mathrm{DF}$ \\
\hline $\begin{array}{l}\text { Overfilling } \\
\text { of GP cone }\end{array}$ & 36 & 2.67 & 0 & 34 & 5 \\
\hline Ledge & 17 & 1.26 & 0 & 16 & 5 \\
\hline
\end{tabular}

$\begin{array}{lccccc}\begin{array}{l}\text { Extensive } \\ \text { calcification }\end{array} & 10 & 0.74 & 4 & 6 & 0 \\ \text { Perforation } & 5 & 0.37 & 0 & 5 & 2 \\ & & & & & \\ \text { Broken file } & 5 & 0.37 & 2 & 4 & 0\end{array}$

$\begin{array}{lccccc}\begin{array}{l}\text { GP overfilling }+ \\ \text { ledge }\end{array} & 4 & 0.29 & 0 & 0 & 4 \\ \begin{array}{l}\text { GP overfilling }+ \\ \text { perforation }\end{array} & 1 & 0.07 & 0 & 0 & 1 \\ \begin{array}{l}\text { Perforation }+ \\ \text { ledge }\end{array} & 1 & 0.07 & 0 & 0 & 1 \\ \begin{array}{l}\text { GP overfilling } \\ + \text { perforation }+\end{array} & 1 & 0.07 & 0 & 0 & 1 \\ \text { ledge } & 80 & 5.93 & 6 & 65 & 19 \\ \begin{array}{l}\text { Total } \\ \text { ledge }\end{array} & & & & & \end{array}$

$\mathrm{GP}=$ gutta-percha; $\mathrm{PF}=$ Perfect; $\mathrm{SF}=$ Satisfactory; $\mathrm{DF}=$ Deficient . 
$(4,10)$ and undergraduate students $(12-16)$. In procedures performed by dental students, $30.1-47 \%$ of the canals were adequately filled $(12,13)$. If the procedure was performed by students in the initial learning phase, this value declined to $13 \%$ (14). However, if it was performed on single-rooted teeth, the results were considered of high quality in $70-80 \%$ of cases $(9,15)$. Conversely, endodontists achieved high technical quality evaluation ranging from $77.4-91.0 \%$ (16) and up to $95.0 \%$ (2). With respect to obturation performed by undergraduate students, apical extension, taper, and homogeneity were considered adequate in $69.0,68.3$, and $53.2 \%$, of the cases, respectively (13), whilst the results of endodontists were $74.0,83.8$, and $86.1 \%$ (16). In the present study, postgraduate students obtained ideal standard scores in $70.52,82.0$ and $94.2 \%$, of the sample, respectively.

In the present study, as reported elsewhere (12), no significant difference was observed concerning the quality standards between maxillary and mandibular root canal fillings. Nevertheless, anterior teeth presented higher technical quality than posterior teeth, which is in agreement with previous studies $(12,13,15,17)$. The highest percentage of inadequate root-filled canals was observed in molar teeth (71.9\%) (17). Although only $8.5 \%$ of the sample were subjected to retreatment, there was no significant difference in terms of the standard quality as a function of the treatment type. Notwithstanding, this study reveals an interesting finding concerning the variation of frequency scores of the radiographic quality parameters of fillings as a function of the specific root canal groups. Therefore, the degree of complexity observed warns to the possible challenges in obtaining ideal filling in all root canal groups. Moreover, the adopted methodology could be a practical and comprehensive strategy for endodontic learning and research regarding root canal fillings.

The radiographic image of root canal obturation reflects the original anatomy of the root canal and reveals specific details about the filling $(8,12,17)$, allowing the assessment of its quality. On the other hand, the varied parameters of radiographic evaluation of the filling quality make comparisons difficult and may generate bias. For example, the majority of the studies evaluated the apical extension and homogeneity of the filling, considering it as adequate when it was $0-2 \mathrm{~mm}$ short of the apex and free of porosities $(3-5,18)$. However, not all of these studies applies these two criteria simultaneously or with the same level of conformity. In the present study, the three fundamental parameters of canal filling were scored as a function of an ideal standard. Moreover, in order to minimize subjectivity and to reduce bias, only radiographs of high quality were included.

Among the evaluated radiographic filling aspects, homogeneity had the highest ideal standard scores. It may be explained by the use of thermoplasticized guttapercha obturation techniques $(2,4,18)$. It is clinically relevant because poor homogeneity of the filling material may lead to microleakage, which is the major cause of apical periodontitis $(3,5,6)$. The taper, which is a less frequently evaluated parameter in the literature $(12,13,16)$, presented the second-best performance. For taper, accentuated deviation was observed at a low rate (3.02\%) and most cases occurred in the mesial root of mandibular molars. These morphological changes may be due to the irregular shaping of root canals. The major challenge in achieving better quality of filling was to maintain an adequate apical extension and adaptation of the master gutta-percha cone in the critical apical zone.

Current discussion is focused on the philosophical aspects of apical extension of instrumentation and filling (19). In the present study, it was observed under- and overfilled root canals in $17.96 \%$ and $11.47 \%$ of the sample, respectively, demonstrating that it is difficult to keep the correct apical extension achieved with K-files during obturation procedures. It was even more critical when considering the mesiobuccal canals of maxillary molars and mesial canals of mandibular molars. The complexity of the root canal system anatomy reflects the highest degree of complexity of the obturation procedures, resulting in mayor prevalence of periapical radiolucency $(4-6,20)$.

In the literature, the prevalence of operative complicating factors on endodontic treatments is extremely variable, ranging from 1.1 to $24.8 \%(8,16,18)$. In the present study, molars represented $81.25 \%$ of the canals involved in operative accidents. Shaping errors possibly influenced the standard quality of the filling as out of 80 root canals with complicating factors, $75.5 \%$ had satisfactory filling and $22.2 \%$ had deficient filling. Intraoperative accidents triplicated the probability of a filling to lose its quality standard $(\mathrm{OR}=3.210 ; 95 \%$ $\mathrm{CI}=1.733-5.949)$.

In conclusion, the radiographic quality of the root canal fillings at a Postgraduate Program in Endodontics varied significantly according to the root canal groups. The combination of radiographic parameters based on apical extension, taper and homogeneity determined three filling complexity degrees. Apical extension was 
the most critical quality parameter in root canal fillings.

\section{RESUMO}

O objetivo deste estudo foi avaliar o padrão de qualidade de 1.347 obturações de canais radiculares realizadas por estudantes de pós-graduação em endodontia, conforme 3 parâmetros radiográficos. Os parâmetros de qualidade analisados incluíram limite apical (LA), conicidade (CO) e homogeneidade (HO), os quais receberam escores E2 (padrão ideal), E1 (suave desvio) ou E0 (desvio acentuado). Obturação perfeita (OP) recebeu E2 em todos os parâmetros. Na ausência de um ou dois E2, as obturações foram consideradas satisfatórias (OS) ou deficientes (OD), respectivamente. Os resultados mostraram 51,7\%, 41,5\% e 6,8\% de OP, OS e OD, respectivamente. LA, CO e HO apresentaram semelhantes parâmetros de qualidade nos canais radiculares de incisivos e pré-molares inferiores $(\mathrm{p}>0,05)$. Em contrapartida, nas obturações de incisivos superiores, caninos e canais distais de molares inferiores, foram encontradas diferenças significativas entre 2 parâmetros $(p<0,05)$. Além disso, houve diferença significativa $(\mathrm{p}<0,05)$ entre os parâmetros medidos em obturações de canais radiculares de pré-molares superiores, todos os canais radiculares de molares superiores e canais mesiais de molares inferiores. LA mostrou a menor frequência de E2 para todos os grupos. Em conclusão, a prevalência de obturações perfeitas, satisfatórias e deficientes variou significativamente em função dos grupos de canais radiculares. Os parâmetros de qualidade categorizaram as obturações em 3 graus de complexidade. LA foi o parâmetro crítico da qualidade das obturações dos canais radiculares.

\section{REFERENCES}

1. Friedman S. Expected outcome in the prevention and treatment of apical periodontitis. In: Essential endodontology. Örstavik D, Pitt Ford T. (Editors). 2nd ed. Oxford, UK: Blackwell Munksgaard Ltd; 2008. p 408-469.

2. Ricucci D, Gröndahl K, Bergenholtz G. Periapical status of rootfilled teeth exposed to the oral environment by loss of restoration or caries. Oral Surg Oral Med Oral Pathol Oral Radiol Endod 2000;90:354-359.

3. Estrela C, Leles CR, Hollanda ACB, Moura MS, Pécora JD. Prevalence and risk factors of apical periodontitis in endodontically treated teeth in a selected population of Brazilian adults. Braz Dent J 2008;19:34-39.

4. Tavares PB, Bonte E, Boukpessi T, Siqueira JF Jr, Lasfargues JJ. Prevalence of apical periodontitis in root canal-treated teeth from an urban French population: influence of the quality of root canal fillings and coronal restorations. J Endod 2009;35:810-813.

5. Ödesjö B, Helldén L, Salonen L, Langeland K. Prevalence of previous endodontic treatment, technical standard and occurrence of periapical lesions in a randomly selected adult, general population. Endod Dent Traumatol 1990;6:265-272.
6. Chueh L-H, Chen S-C, Lee C-M, Hsu Y-Y, Pai S-F, Kuo M-L, et al.. Technical quality of root canal treatment in Taiwan. Int Endod J 2003;36:416-422.

7. Mayhew RB, Svee TA, Johnson CW, Markins SR. Quality of obturation in student cases instructed by endodontic versus general dentistry faculty. J Endod 1999;25:461-463.

8. Pettiette MT, Metzger Z, Philips C, Trope M. Prognosis of root canal therapy performed by dental students with stainless steel K-files and NiTi hand files. J Endod 1999;25:230-234.

9. Lynch CD, Burke FM. Quality of root canal fillings performed by undergraduate dental students on single-rooted teeth. Eur J Dent Educ 2006;10:67-72.

10. Molander A, Caplan D, Bergenholtz G, Reit C. Improved quality of root fillings provided by general dental practitioners educated in nickel-titanium rotary instrumentation. Int Endod J 2007;40:254260.

11. Tu MG, Chen SY, Huang HL, Tsai CC. Endodontic shaping performance using nickel-titanium hand and motor ProTaper systems by novice dental students. J Formos Med Assoc 2008;107:381-388

12. Barrieshi-Nusair KM, Al-Omari MA, Al-Hiyasat AS. Radiographic technical quality of root canal treatment performed by dental students at the Dental Teaching Center in Jordan. J Dent 2004;32:301-307.

13. Er O, Sagsen B, Maden M, Cinar S, Kahraman Y. Radiographic technical quality of root fillings performed by dental students in Turkey. Int Endod J 2006;39:867-872.

14. Hayes SJ, Gibson M, Hammond M, Bryant ST, Dummer PMH. An audit of root canal treatment performed by undergraduate students. Int Endod J 2001;34:501-505.

15. Pettigrew LK, Jauhar S, Lynch CD, Savarrio L, Carrotte P, Hannigan A. An audit of the quality of root canal treatments performed by undergraduate dental students on single-rooted teeth in Glasgow dental hospital and school. Eur J Prost Restor Dent 2007;15:72-76.

16. Bierenkrant DE, Parashos P, Messer HH. The technical quality of nonsurgical root canal treatment performed by a selected cohort of Australian endodontists. Int Endod J 2008;41:561-570.

17. Moussa-Badran S, Roy B, Bessart du Parc AS, Bruyant M, Lefevre B, Maurin JC. Technical quality of root fillings performed by dental students at the dental teaching centre in Reims, France. Int Endod J 2008;41:679-684.

18. Eleftheriadis GI, Lambrianidis TP. Technical quality of root canal treatment and detection of iatrogenic errors in an undergraduate dental clinic. Int Endod J 2005;38:725-734.

19. Ricucci D. Apical extension of root canal instrumentation and obturation, part 1. Literature review. Int Endod J 1998;31:384-393.

20. Imura N, Pinheiro ET, Gomes BP, Zaia AA, Ferraz CC, SouzaFilho FJ. The outcome of endodontic treatment: a retrospective study of 2000 cases performed by a specialist. J Endod 2007;33:1278-1282.

Accepted March 30, 2010 